\title{
Cultural Values and the Coliform Bacterial Load of "Masato," an Amazon Indigenous Beverage
}

\author{
Alejandra Bussalleu, ${ }^{1}$ Aldo Di-Liberto, ${ }^{1}$ Cesar Carcamo, ${ }^{1}$ Gabriel Carrasco-Escobar, ${ }^{1,6}$ \\ Carol Zavaleta-Cortijo (D, ${ }^{2,7}$ Matthew King, ${ }^{3}$ Lea Berrang-Ford, ${ }^{4}$ Dora Maurtua, ${ }^{5}$ \\ Alejandro Llanos-Cuentas, ${ }^{1}$ and Indigenous Health and Adaption to Climate Change Research \\ Group (IHACC) \\ ${ }^{1}$ Facultad de Salud Pública y Administración, Universidad Peruana Cayetano Heredia, Av. Honorio Delgado 430, Lima 31, Peru \\ ${ }^{2}$ Department of Population Medicine, University of Guelph, 50 Stone Road East, Guelph, ON N1G 2W1, Canada \\ ${ }^{3}$ Geography Department, McGill University, Burnside Hall Building, Room 705, 805 Sherbrooke Street West, Montreal, QC H3A0B9, Canada \\ ${ }^{4}$ Priestley International Centre for Climate, University of Leeds, Woodhouse Lane, Leeds LS2 9JT, UK \\ ${ }^{5}$ Laboratorio de Bacteriología de los Laboratorios de Investigación y Desarrollo, Facultad de Ciencias y Filosofía, Universidad Peruana Cayetano \\ Heredia, Av. Honorio Delgado 430, Lima 31, Peru \\ ${ }^{6}$ Division of Infectious Diseases, Department of Medicine, University of California San Diego, La Jolla, CA, USA \\ ${ }^{7}$ Present address: Facultad de Salud Pública y Administración, Universidad Peruana Cayetano Heredia, Av. Honorio Delgado 430, Lima 31, Peru
}

\begin{abstract}
Access to safe drinking water is limited in many isolated areas, such as the Amazon where Indigenous peoples frequently reside. Identifying safe forms of drinking water accepted by the communities could have positive health benefits for Indigenous peoples. Many Amazon Indigenous peoples traditionally prepare and consume a fermented beverage called masato, which is frequently the only form of water consumption. Despite its widespread consumption and evidence of the health benefits of fermentation, masato remains poorly investigated. We partnered with a Shawi Indigenous community in the Peruvian Amazon to conduct participatory photography to research masato preparation, and to characterize key cultural features and to assess the presence of total and fecal coliform bacteria by using a membrane filter technique. Pictures show that masato preparation is a key part of cultural practices and that there are clear gender roles in the preparation process. We found that $100 \%$ of communal water sources (26/26) were contaminated with coliform bacteria; by contrast, fewer, $18 \%$ of masato samples $(2 / 11)$, were positive for coliform. This exploratory study suggests that fermented beverages like masato merit further investigation as they represent an Indigenous method to improve water quality in Amazonian communities where water safety cannot be assured.
\end{abstract}

Keywords: Water safety, Fermentation, Indigenous food, Amazonia, Shawi, Peru, Masato, Indigenous knowledge

Published online: November 20, 2020 


\section{INTRODUCTION}

Access to safe drinking water is essential for human health. Though estimates indicate drinking water is accessible to over three quarters of the global population, access to clean water and sanitation are far from universal in most lowand middle-income countries (Guardiola et al. 2010). Access to safe drinking water is especially limited for Indigenous populations located in the Amazon (Miranda et al. 2010). Indigenous communities in the Amazon often draw their water directly from rivers, streams, and lakes (Leite et al. 2013; McClain et al. 2001). Microbiological (i.e., bacterial, parasitic, and viral pathogens) and chemical (e.g., chemicals related to oil extraction) contaminants in untreated water present a risk to human health. Even in communities where water treatment campaigns have been implemented, researchers have found that less than half of the population in these Indigenous communities report boiling or treating water with chlorine before consumption (Brierley et al. 2014; Hofmeijer et al. 2013; INEI 2008; Nawaz et al. 2001). The lack of adoption of water treatment highlights the need to identify and understand Indigenous values and motivations associated with drinking water, and potential local alternatives for providing safe and culturally acceptable drinking water. Improved access to safe drinking water in the Amazon region could lead to positive health impacts for Indigenous peoples.

Across the Amazon region, there is a common practice among Indigenous communities of preparing and drinking a beverage called masato (Freire et al. 2016; Sedano 2006). Masato is the primary, and sometimes exclusive, form of water consumption (Torres-Slimming et al. 2019). It is a fermented beverage that has a low alcohol content and a slightly sweet and acidic taste (Sedano 2006). Women are usually responsible for the preparation of masato via boiling and mashing cassava, which is commonly known as "yuca" in Spanish and "kisha" in the Shawi language (Colehour et al. 2014; Sedano 2006; Zavaleta et al. 2017). Masato is also a culturally important beverage; for instance, research has shown that masato is widely consumed and culturally acceptable among Shawi communities in Peru (Hofmeijer et al. 2013; Ormaeche Macassi 2008; Zavaleta et al. 2018). Women masticate (chew) pieces of boiled cassava and periodically spit them into a mash. By consequence, in addition to the normal environmental community of microbes, human microbiota are also incorporated into the beverage during the fermentation process (Colehour et al. 2014).

Despite the potential health benefits of fermentation and the widespread consumption of masato in many Amazon Indigenous communities, neither the fermentation process per se, nor the microbiological characteristics of masato have been researched thoroughly (Freire et al. 2016). Studies suggest that the use of fermentation techniques has beneficial protective properties as the process may protect against microbial contamination with harmful pathogens, thus reducing risk of diarrheal disease (Marco et al. 2017; Şanlier et al. 2019; Watson et al. 1996). Diarrheal illness is a public health concern, particularly among children and Indigenous populations in the Peruvian Amazon. According to a recent study, the prevalence of reported acute diarrheal events using a 15-day recall period was 19\% among children in the Loreto region (Perú 2018), increasing to $50 \%$ in Indigenous children in the region of Amazonas in northern Peru (Diaz et al. 2015). A better characterization of cultural importance of masato for Indigenous communities and understanding the microbiological profile of masato could contribute to establishing a public health response that is embedded in Indigenous knowledge and norms in Amazon Indigenous communities, especially where water potabilization is not yet implemented.

The aim of this research was to: (1) characterize key cultural features of masato with Shawi participants through participatory photography and (2) investigate the presence of total and fecal coliform bacteria in samples of masato compared to other communal water sources.

\section{MetHOdS}

This study is part of a larger, community-based research initiative focused on examining social and environmental drivers of health in remote Indigenous communities in Peru. The research methods and informed consent processes were approved by the Cayetano Heredia University Institutional Review Board, and the research ethics boards at McGill University, the University of Guelph, and the University of Alberta.

The research project took place in a Shawi Indigenous community located by the Armanayacu River, in the Balsa Puerto Amazonas District of the Loreto region in Peru. 
During initial research in 2012, Shawi participants reported that food and water security were key health concerns related to recent social and environmental changes (Hofmeijer et al. 2013). Further, in 2014, Shawi participants used Photovoice to demonstrate the importance of masato as a key component of their daily diet (Zavaleta et al. 2018). Building on these previous results, we conducted microbiological testing of masato in November 2015 to explore its bacteriological properties and a follow-up photographic study in July 2017 to visually characterize practices, concepts, and key messages that participants chose to communicate about this traditional beverage.

\section{Photographic Study}

Research has shown that photographic narratives are effective in promoting social change, balancing power, fostering trust, and recognizing ownership of Indigenous knowledge (Castleden et al. 2008; Harper et al. 2012; Lardeau et al. 2011). Beginning in 2012, the primary researchers ( $A B$ and $C Z C)$ have worked and lived within the community for a duration of 1-3 months annually. The photographer/researcher (MK) lived in the community for 2 months to establish a rapport and trust with community members. During the data collection in 2017, the photographer/researcher conducted informal, conversational interviews with community members and iteratively presented options for times and places for community members to be photographed, and to identify and prioritize what they wanted to communicate to others in Peru and abroad about masato. Photographs were classified into four main themes that represented the main food-related activities that community members practiced: eating, hunting, fishing, and farming. Masato emerged across all four themes, being the preferred way to quench thirst of Shawi participants. (To see further descriptions of this work and food-related themes, see Web site https://adapta ndoparacomer.weebly.com/.) During community dissemination workshops in January 2018, Shawi community members validated the themes and final selection of photographs.

\section{Microbiological Study}

In November 2015, a total of 37 water samples-19 household water samples, 11 masato samples, and 7 samples from outdoor drinking water sources (river, streams, and wells)—were collected over a 3-day period. We used purposive sampling to select households. Head of the households provided household water and masato samples in plastic or ceramic pots. Researcher then transferred the samples to sterile Whirl-Pak (Ziploc ${ }^{\circledR}$ ) bags and placed them in a cooler at room temperature for transportation. For outdoor water sources, samples were taken far from the water's edge and at medium depth, immersing the sampling bag into the direction of the current and approximately $15-20 \mathrm{~cm}$ below the water surface. Sites contaminated with garbage or close to sewage were avoided, as well as the collection of surface scum and sediment. Around $300 \mathrm{ml}$ of liquid was collected from each drinking water source in a sterile Whirl-Pak bag and immediately put in a cooler for transportation.

Samples were processed in the community immediately after they were collected, within 20-30 min of collection. The working area was provided by the community—a room with no air current and no human or animal transit-and was intensely cleaned before sample manipulation. We used a membrane filter technique for detecting the presence of total and fecal coliform bacteria (American Public Health Association, American Water Works Association, \& Water Environment Federation 1998). Masato samples were filtered using a sterile strainer to remove floating organic particles before dilution. Water and masato samples underwent serial dilutions with distilled water (two dilutions of 1:100); $100 \mathrm{ml}$ of the last dilution was filtered through a cellulose filter membrane of pore size $0.22 \mu \mathrm{m}$ and diameter $47 \mathrm{~mm}$ before placing them in Hach's m-ColiBlue 24 Broth for cultivating. Inoculated plates (one per sample) were incubated at $35{ }^{\circ} \mathrm{C}$ for $24 \mathrm{~h}$ in a portable $12 \mathrm{~V}$ incubator connected to a car battery.

Total and fecal coliform counting was performed as presented in Hach's Analytical Procedures protocol (Hach Company. Analytical Procedures. Coliforms: Membrane Filtration. 1999. USA). Chromogenic media discriminates Escherichia coli colonies as blue from other coliforms which show a red color.

\section{Results}

\section{Masato Key Cultural Features}

Masato had cultural importance for Indigenous Shawi in the Peruvian Amazonia. Pictures in Fig. 1 illustrate how Shawi study participants transform cassava to drinkable 
masato: from cropping, cleaning and washing, cooking, mashing, resting for fermentation, to drinkable masato.

Along this process, there were a series of stages that were deeply rooted in Indigenous sociocultural practices and closely related to the benefits of natural ecosystems. For example, even though masato was exclusively prepared by women in all the study households, men also played a key role in the process. Men cleared the land for planting cassava (Fig. 1a) and fabricated wooden tools (Fig. 1n, o). Wood from the forest and mud from the river bed are used for making the utensils used in masato preparation. The fermentation of masato can take between 1 and 3 days, depending on preference, although some participants explained 1 day of fermentation may not be sufficient to produce masato that is safe to drink. A longer fermentation time is also preferred when the beverage is intended for consumption during a celebration. When ready for consumption, a portion of the fermented masato mash is combined with communal water sources to produce the drinkable version of masato. Figure $11, \mathrm{~m}$ shows both stages of masato - the mash before being combined with water and the final drinkable beverage. In these Shawi communities, men were usually responsible for providing meat from the forest by hunting. When they go hunting, men reported taking masato mash with them to prepare masato along the road, as their source of drinking water (Fig. 11).

\section{Coliform Presence in Masato}

Coliform bacteria grew in all plates inoculated with water from household (19/19) and outdoor (7/7) sources. Colony-forming unit (CFU) counts for household water cultures varied from $1.4 \times 10^{3}$ to $18.5 \times 10^{3}$ to numbers too numerous to count (TNTC) per $1 \mathrm{ml}$ (Table 1 ).

Cultures from river, streams, and wells showed a higher load of coliform bacteria colonies than masato samples. Nine of eleven masato samples showed no bacterial growth (Table 2) $(P<0.001$, Fisher's exact test $)$.

Figure 1 shows the proportion of water samples with the presence of fecal coliform from each category: outdoor, household, and masato (Fig. 2).

\section{Discussion}

A paradigm shift is needed in the public health community and health sector to consider and assess fermented Indigenous preparations, such as masato, as part of the
Figure 1. Masato preparation in one Shawi Indigenous community of the Peruvian Amazon. Shawi Indigenous people of the Peruvian Amazon transform cassava into a fermented beverage called masato. This series of pictures show the different stages of masato production: from planting cassava to preparing the beverage. It includes the cultural Shawi gender roles throughout the process. The typical preparation process is as follows: a The father or an adult male will initially clean and prepare the cassava garden; $\mathbf{b}$ then a women will plant and harvest the cassava, as well as weed the garden, while the cassava grows; c women harvest and select the cassava; $\mathbf{d}$ cassava is peeled and placed in traditional baskets that are typically made (knitted) by men; e cassava is carefully washed in the river by one woman, and water from this same river is used to boil the cassava; $\mathbf{f}$ cassava is placed in a big pot with water for boiling and water is transported from the river to boil the cassava; $\mathbf{g}$ boiled cassava is placed in a wooden container for mashing; $\mathbf{h}$ at this stage sweet potato, sugar cane juice, and, when in season, sachapapa (purple potato), are added; $\mathbf{i}$ at this point, women chew a portion of the cassava to enhance the flavor and the women's saliva is one of the main sources of the microbial community present in masato; $\mathbf{j}$ then, the masato is ready to sit overnight before it is drank; $\mathbf{k}$ big clay containers are used for storing and fermenting the Masato; 1 a portion of the masato mash is set apart in a bowl to later be mixed with communal water (e.g., river or stream) for the preparation of the masato beverage, drunk to quench thirst, for men during hunting; $\mathbf{m}$ the masato beverage served in a mocahua bowl; $\mathbf{n}$ the wooden instruments used in cassava production are usually made by the father of the family; and, finally, o the oldest father of a household is carving a piece of wood to prepare a ladle, and his wife and daughter will use it in the preparation of masato. Note Pictures were taken during a photographic project in July 2017. All participants have provided their written consent to utilize pictures for academic and educative purposes.

local alternatives and technologies for treating contaminated water (Watson et al. 1996) and improving human health (Chilton et al. 2015). Our study demonstrates that coliform bacteria were significantly lower in masato compared with other sources of water in this location, suggesting additional health benefits of the beverage that have not previously been understood. This study is in agreement with a previous investigation of a similar fermented cassava beverage called "chicha" in Ecuador that also did not find fecal coliforms (Cox et al. 1987). Moreover, a recent study conducted among Indigenous people in the Amazon region of Bolivia suggested that water-rich foods, including cassava fermented beverage, represented a complex dietary adaptation to reduce exposure to pathogens from unsafe water (Rosinger and Tanner 2015). 
(a)

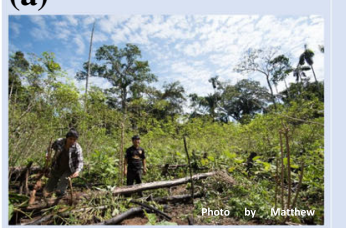

(b)

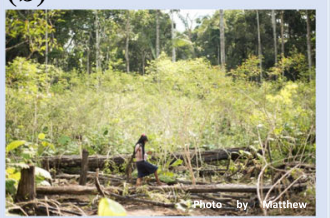

(c)

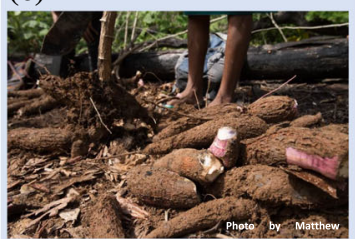

(d)

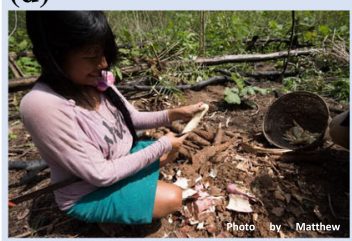

(e)

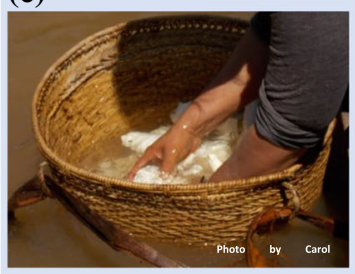

(f)

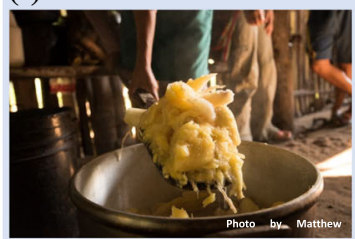

(g)

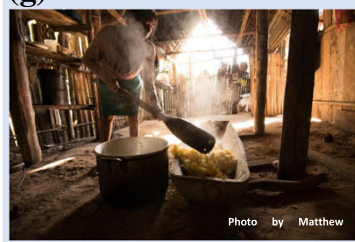

(h)

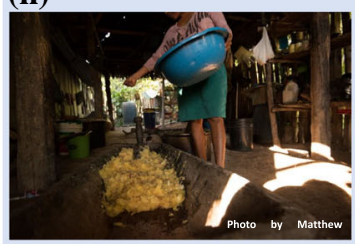

(i)

irst, the father or an adult man will

garden.

Then the women will plant and

Then the women will plant and
harvest the cassava, as well as weed the garden while growing.

Women harvest and select the cassava.

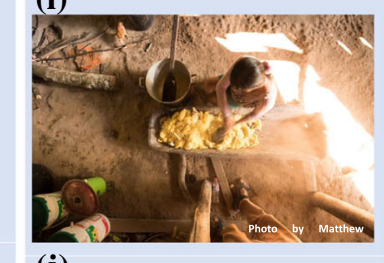

(j)

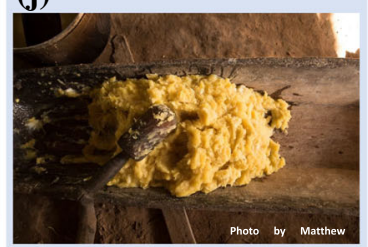

At this stage the masato is drunk

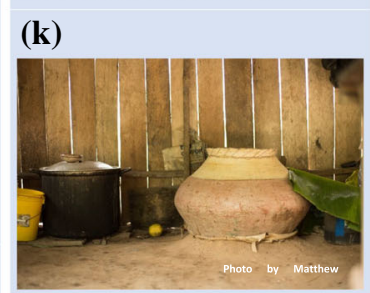

Big clay container for storing
and fermenting the Masato

(l)

Cassava is peeled and placed in
traditional baskets, which are typically made (knitted) by me

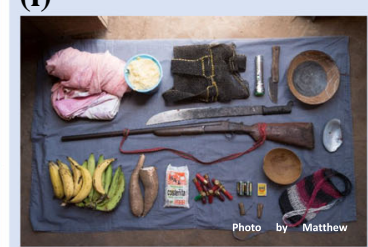

A portion of the masato dough is set apart in a bowl to later be mixed with communal
water (e.g. river or stream) to picture shows masto. This as a key element for men to go to the forest for hunting.

A woman carefully washes the cassava in the river. Water from
this same river is used to boil the cassava.

\section{(m)}

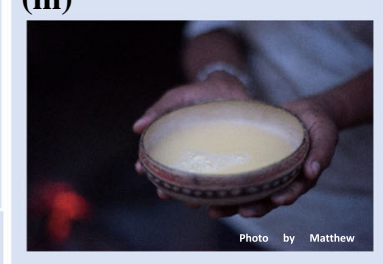

This picture shows masato beverage served in a mocahua bowl

\section{(n)}

pot with water for boiling. Water boil the cassava

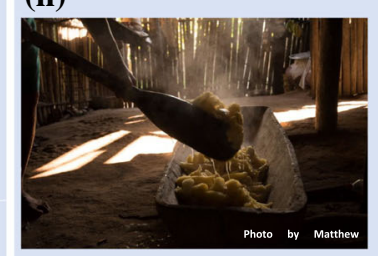

The wooden instruments used in masato production are usually made by the father in the family

\section{(o)}

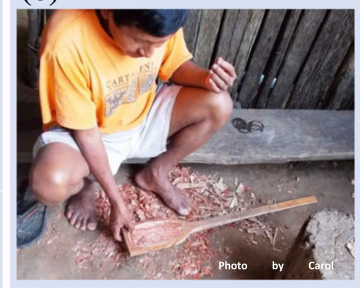
household is carving a piece of wood to prepare a ladle, which will be used by his wife and masato potato), are added. masato 


\section{The Public Health Importance of Masato}

Previous studies have reported on the nutritional importance of masato because it is made from locally available and locally produced cassava tubers (Creed-Kanashiro et al. 2009; Peña-Venegas et al. 2014). However, beyond its nutritional value, our findings suggest that masato is important because it is a culturally acceptable method to treating and drinking water in communities where potable water remains limited. Not only is it acceptable, masato preparation is embedded in Indigenous knowledge and also holds important cultural value for Indigenous people of the Amazon. As such, interest arises for its public health implications, embedded in Indigenous knowledge, for reducing the burden of waterborne diseases, especially in areas where access to clean water is not yet guaranteed.

Furthermore, our results raise the possibility that Indigenous masato preparation and consumption may be currently supporting a reduced burden of waterborne disease in Shawi and/or Amazonian communities. In 2007, a report from the Peruvian Ministry of Health found that for Shawi children between 1 and 19 years old, acute diarrhea was an important reason for consultation (Ormaeche Macassi 2008). Twenty-two percent of the youngest age-group (1-4 years old) had diarrhea (see "Appendix"); however, when we compared that rate with the results of the $\mathrm{Na}$ tional Demographic and Family Health Survey for Peru in the same year 2007 (INEI 2009), the prevalence of acute diarrhea was $29 \%$ among children under 5 years old of Loreto Amazon region. Given that Shawi children drank masato, it suggests that fermented masato could have an implication on reducing acute bacterial diarrhea infections among young Shawi children.

The absence of coliform bacterial growth in most of the masato cultures in this study might be explained by the presence of alcohol and lactic acid product of the fermentation process involved in masato preparation. Motarjemi (2002), Şanlier et al. (2017), and O'Sullivan et al. (2002) indicate that the processes of fermentationspecifically lactic fermentation-inhibit the growth and survival of a variety of pathogenic organisms.

The high load of total and fecal coliforms found in the water sources of the community, other than masato, may be due to contamination of the main source of domestic water, the Armanayacu River. River water contamination stems from multiple factors, including open defecation by the river despite the availability of a few latrines in the community (Torres-Slimming et al. 2019). Additionally, wild and domestic animals (e.g., cattle and pigs) also roam river banks, adding to potential sources of water contamination. The high level of contamination in the communal water sources found in this study indicates that Shawi Indigenous communities are exposed to high risks if they would decide to drink water directly from natural sources, making the consumption of masato even more crucial while other public health solutions are being implemented.

\section{Future Research}

In this study, all masato samples were provided by the head of the households, and handwashing and serving practices may have varied by household. Shawi have reported that they wash their hands before serving masato, although use of soap is not a common practice (Torres-Slimming et al. 2019). Future studies could analyze coliform load per preparation method, days of fermentation, and the effect of unwashed hands on coliform presence. Nonetheless, contamination post-fermentation could less of a problem with alcohol-containing beverages, as it will kill the pathogens on contact.

Future research should consider microbial testing beyond total and fecal coliform; analyzing masato samples along the multiple stages of its processing; determining practices that reduce the risk of contamination of masato; determining the mechanisms of microbiological clearing during the fermentation process (including the presence of microorganisms, ethanol, and lactic acid); and determining the direct or indirect effects of masato on the well-being of Indigenous people.

Furthermore, researchers have also suggested that beyond the health benefits of fermented Indigenous foods and beverages, these items could provide economic opportunities for improving Indigenous livelihoods (Marsh et al. 2014; Marshall and Mejia 2011). Future research assessing the economic role of masato in communities may be of value.

One limitation of our study was that we were not able to confirm the exact number of days of fermentation that each masato sample underwent. Variations in masato preparation methods were beyond the scope of this study; however, variations in preparation method may explain why 2 of the 11 masato samples showed coliform presence. 
Table 1. Total and Fecal Coliform Count Per $1 \mathrm{ml}$ from Water Samples Collected in a Shawi Community in the Amazon of Peru.

\begin{tabular}{|c|c|c|c|}
\hline Sample & Source & Total coliform count & Fecal coliform count \\
\hline 1 & Household (collected from the river) & TNTC & $4.2 \times 10^{3}$ \\
\hline 2 & Household (collected from the river) & TNTC & TNTC \\
\hline 3 & Household (collected from the river) & TNTC & TNTC \\
\hline 4 & Household (collected from the river) & TNTC & $6 \times 10^{3}$ \\
\hline 5 & Household (collected from the river) & TNTC & $18.5 \times 10^{3}$ \\
\hline 6 & Household (collected from the river) & TNTC & $4.2 \times 10^{3}$ \\
\hline 7 & Household (collected from the river) & TNTC & TNTC \\
\hline 8 & Household (collected from the river) & TNTC & TNTC \\
\hline 9 & Household (collected from the river) & TNTC & TNTC \\
\hline 10 & Household (collected from the river) & TNTC & TNTC \\
\hline 11 & Household (collected from the river) & TNTC & TNTC \\
\hline 12 & Household (collected from the river) & TNTC & TNTC \\
\hline 13 & Household (collected from the river) & TNTC & TNTC \\
\hline 14 & Household (collected from a stream) & TNTC & TNTC \\
\hline 15 & Household (collected from a stream) & TNTC & TNTC \\
\hline 16 & Household (collected from a stream) & TNTC & $18 \times 10^{3}$ \\
\hline 17 & Household (collected from a well) & TNTC & $2 \times 10^{3}$ \\
\hline 18 & Household (collected from a well) & TNTC & $1.4 \times 10^{3}$ \\
\hline 19 & Household (collected from a well) & TNTC & $8 \times 10^{3}$ \\
\hline 20 & River & TNTC & $1.6 \times 10^{3}$ \\
\hline 21 & River & TNTC & TNTC \\
\hline 22 & River & TNTC & TNTC \\
\hline 23 & River & TNTC & TNTC \\
\hline 24 & Stream & TNTC & TNTC \\
\hline 25 & Stream & TNTC & $17.2 \times 10^{3}$ \\
\hline 26 & Well & TNTC & $3.1 \times 10^{3}$ \\
\hline
\end{tabular}

TNTC too numerous to count.

Table 2. Total and Fecal Coliform Count for $1 \mathrm{ml}$ from masato Samples Collected in a Shawi Community in the Amazon of Peru.

\begin{tabular}{llll}
\hline Sample & Source & Total coliform count & Fecal coliform count \\
\hline 1 & Masato & Negative & Negative \\
2 & Masato & Confluent growth & Confluent growth \\
3 & Masato & Negative & Negative \\
4 & Masato & Negative & Negative \\
5 & Masato & Negative & Negative \\
6 & Masato & TNTC & TNTC \\
7 & Masato & Negative & Negative \\
8 & Masato & Negative & Negative \\
9 & Masato & Negative & Negative \\
10 & Masato & Negative & Negative \\
11 & Masato & Negative & Negative \\
\hline
\end{tabular}

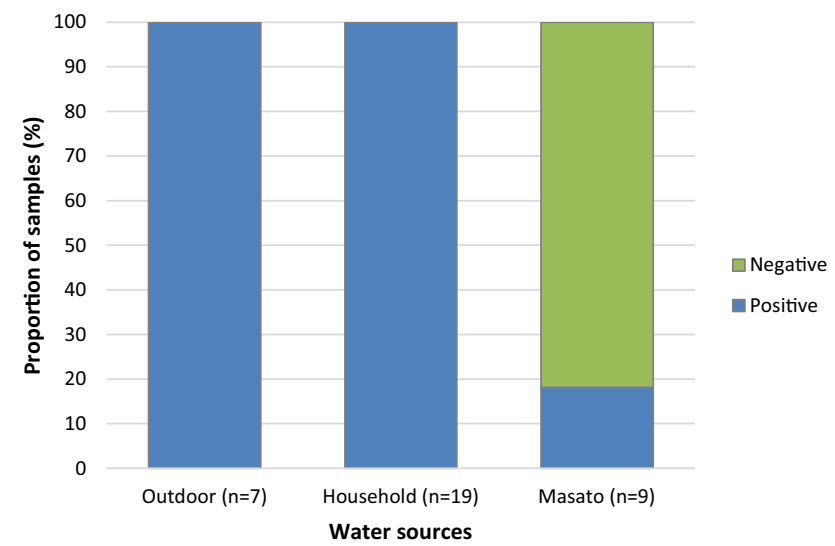

Figure 2. Presence of fecal coliform in water samples collected in a Shawi community in the Amazon of Peru. 


\section{The Importance of Culture and a Gender Approach to Promote Water Security}

Our study found that masato preparation involved the participation of both men and women, suggesting that gendered cultural roles are also associated with the preparation and consumption of masato. It highlights the social function that this fermented beverage has for Indigenous peoples such as the Shawi in the Amazon region (González 2013). Our findings concur with previous studies that have reported on the importance, acceptability and the participation of women and men in producing masato among Shawi people from other communities (González 2013; Ormaeche and Valdez 2003).

Our results concur with research that posits that water treatment among remote Indigenous communities is not only a matter of implementing conventional forms of improving water quality (Jaravani et al. 2016; Wright et al. 2018). Clean water interventions need to consider local perceptions and cultural aspects, including the female and male responsibilities in assuring safe drinking water for family members and water utilization. For example, among some Indigenous communities in the global north, researchers reported that women perceive greater risks associated with the safety of drinking water than males, making female participation and knowledge key in designing water-related interventions (Dupont et al. 2014; Spence and Walters 2012). Moreover, designing culturally appropriate water treatment interventions that are embedded in Indigenous knowledge and practices avoids the colonial impacts that Indigenous populations, worldwide and in Peru, have experienced (Axelsson et al. 2016; Gracey and King 2009; Stephens et al. 2006).

\section{CONCLUSION}

This study showed that masato plays an important role in reducing microbial contamination of untreated local water sources among Shawi participants. In addition, results show that there are Indigenous sociocultural implications related to this fermented beverage, including gender responsibilities during the preparation process. To warrant masato as a safe drinking water alternative, further investigation is needed on masato microbiological safety. Demonstrating the microbiological safety of masato could present important public health benefits for Indigenous communities where clean water cannot yet be guaranteed, as it is a culturally accepted drinking water alternative. To ensure the success of interventions aimed at improving access to drinking water, Indigenous community members must be active members of any intervention design.

\section{ACKNOWLEDGEMENTS}

This study was conducted at the Shawi community of Nuevo Progreso in the Armanayacu watershed. We express our sincerest gratitude to Shawi community members including authorities and research assistants for accepting us in their community, and especially to household members who kindly provided samples of their Masato to conduct this study. We acknowledge the participation of Tito Marden Chanchari Huiñapi, Elvis Lancha Huiñapi, Guillermo Lancha Rucoba and Pedro Pizango Tangoa as Shawi interpreters and research assistants in this study. We gratefully acknowledge the help of Irene Hofmeijer and Carlee Wright in proofreading and editing the manuscript, and Dr. Sheri Lee Harper for providing her expertise to better represent Indigenous realities.

Indigenous Health Adaptation to Climate Change Research Team: Patricia Garcia, Sherilee L. Harper, Victoria Edge, James Ford, Shuaib Lwasa, and Didacus B. Namanya.

\section{FUNDING}

We received funding from: The International Development Research Centre (IDRC) of Canada, the Canadian Institutes of Health Research, and the Global Health Research Capacity Strengthening Program. CZ was partially funded by University of Guelph, University of Alberta and the National Institute for Health Research (NIHR) (using the UK's Official Development Assistance (ODA) Funding) and Wellcome (218743/Z/19/Z) under the NIHR-Wellcome Partnership for Global Health Research. The views expressed are those of the authors and not necessarily those of Welcome, the NIHR or the Department of Health and Social Care.

\section{Data Availability}

Pictures generated during the current study and informed consents are publicly available at the following address: $h$ ttps://adapttoeatperu.weebly.com/. Additional pictures are available from the corresponding author on reasonable request. All the microbiological data that support the findings in this study are already included in the article. 


\section{Compliance with Ethical Standards}

Ethical ApProval All procedures performed in studies involving human participants were in accordance with the ethical standards of the institutional and/or national research committee and with the 1964 Declaration of Helsinki and its later amendments or comparable ethical standards.

INFORMED CONSENT Informed consent was obtained from all individual participants included in the study. Additional informed consent was obtained from all individual participants for whom identifying information is included in this article, for example in pictures.

\section{Open Access}

This article is licensed under a Creative Commons Attribution 4.0 International License, which permits use, sharing, adaptation, distribution and reproduction in any medium or format, as long as you give appropriate credit to the original author(s) and the source, provide a link to the Creative Commons licence, and indicate if changes were made. The images or other third party material in this article are included in the article's Creative Commons licence, unless indicated otherwise in a credit line to the material. If material is not included in the article's Creative Commons licence and your intended use is not permitted by statutory regulation or exceeds the permitted use, you will need to obtain permission directly from the copyright holder. To view a copy of this licence, visit http://creativec ommons.org/licenses/by/4.0/.

\section{APPENDIX}

See Table 3.

Table 3. Description of the Most Frequent Pathologies that Explains up to the $80 \%$ of the Morbidity Among Shawi Children who Visited Local Health Service at the Balsa Puerto District Between Years 2002 and 2007. Source: Ormaeche Macassi (2008).

\begin{tabular}{|c|c|c|c|}
\hline & Between 1 year old and 4 years old & Between 5 years old and 9 years old & $\begin{array}{l}\text { Between } 10 \text { years old and } 19 \text { years } \\
\text { old }\end{array}$ \\
\hline & Total visits $=10,292$ & Total visits $=18,485$ & Total visits $=19,618$ \\
\hline First & Other intestinal parasites $(30 \%)$ & Other intestinal parasites $(18 \%)$ & Malaria (17\%) \\
\hline Second & $\begin{array}{l}\text { Other upper acute respiratory } \\
\text { infections }(29 \%)\end{array}$ & Malaria $(17 \%)$ & Iron deficiency anemia $(15 \%)$ \\
\hline Third & $\begin{array}{l}\text { Diarrhea and other stomach con- } \\
\text { ditions probably infections } \\
(22 \%)\end{array}$ & $\begin{array}{l}\text { Acute upper respiratory infections, acute } \\
\text { pharyngitis and bronchitis and bronchiolitis } \\
(18 \%)\end{array}$ & Other intestinal parasites $(11 \%)$ \\
\hline \multirow[t]{2}{*}{ Fourth } & & Iron deficiency anemia (9\%) & $\begin{array}{l}\text { Other upper acute respiratory } \\
\text { infection and acute pharyngitis } \\
(14 \%)\end{array}$ \\
\hline & & Other types of physical trauma $(6 \%)$ & Other types of physical trauma (7\%) \\
\hline Fifth & & Skin and subcutaneous infections $(6 \%)$ & $\begin{array}{l}\text { Skin and subcutaneous infections } \\
\qquad(4 \%)\end{array}$ \\
\hline Sixth & & $\begin{array}{l}\text { Conjunctivitis and other conditions of the con- } \\
\text { junctive }(7 \%)\end{array}$ & $\begin{array}{l}\text { Other conditions of the urinary sys- } \\
\text { tem }(4 \%)\end{array}$ \\
\hline Seventh & & Cavity $(3 \%)$ & $\begin{array}{l}\text { Conjunctivitis and other conditions } \\
\text { of the conjunctive }(2 \%)\end{array}$ \\
\hline Eight & & & Cavity $(\% 2)$ \\
\hline Ninth & & & $\begin{array}{l}\text { Diarrhea and other stomach condi- } \\
\text { tions, probably infections }(2 \%)\end{array}$ \\
\hline Ten & & & Other anemias $(2 \%)$ \\
\hline
\end{tabular}




\section{REFERENCES}

American Public Health Association, American Water Works Association, \& Water Environment Federation (1998) Membrane filter technique for members of the coliform group. In: Standard Methods for the Examination of Water and Wastewater (20th ed.).

Axelsson P, Kukutai T, Kippen R (2016) The field of Indigenous health and the role of colonisation and history. Journal of Population Research 33(1):1-7. https://doi.org/10.1007/s12546016-9163-2

Brierley CK, Suarez N, Arora G, Graham D (2014) Healthcare access and health beliefs of the indigenous peoples in remote Amazonian Peru. Am J Trop Med Hyg 90(1):180-183. https:// doi.org/10.4269/ajtmh.13-0547

Castleden H, Garvin TFirst Nation, H.-a.-a. (2008) Modifying photovoice for community-based participatory Indigenous research. Social Science \& Medicine 66(6):1393-1405. https:// doi.org/10.1016/j.socscimed.2007.11.030

Chilton S, Burton J, Reid G (2015) Inclusion of fermented foods in food guides around the world. Nutrients 7(1):390-404

Colehour AM, Meadow JF, Liebert MA, Cepon-Robins TJ, Gildner TE, Urlacher SS, Bohannan BJ, Snodgrass JJ, Sugiyama LSJP (2014) Local domestication of lactic acid bacteria via cassava beer fermentation. PeerJ 2:e479

Cox L, Caicedo B, Vanos V, Heck E, Hofstaetter S, Cordier J (1987) A catalogue of some ecuadorean fermented beverages, with notes on their microflora. MIRCEN Journal of Applied Microbiology and Biotechnology 3(2):143-153

Creed-Kanashiro H, Roche M, Cerron IT, Kuhnlein H (2009) Traditional food system of an Awajun community in Peru. In Indigenous peoples' food systems: the many dimensions of culture, diversity, pp 59-81

Diaz A, Arana A, Vargas-Machuca R, Antiporta D (2015) Health and nutrition of indigenous and nonindigenous children in the Peruvian Amazon/Situacion de salud y nutricion de ninos indigenas y ninos no indigenas de la Amazonia peruana. Revista Panamericana de Salud Pública 38(1):49-57

Dupont D, Waldner C, Bharadwaj L, Plummer R, Carter B, Cave K, Zagozewski R (2014) Drinking water management: health risk perceptions and choices in First Nations and non-First Nations communities in Canada. International Journal of Environmental Research Public Health 11(6):5889-5903

Freire AL, Zapata S, Mosquera J, Mejia ML, Trueba G (2016) Bacteria associated with human saliva are major microbial components of Ecuadorian indigenous beers (chicha). PeerJ 4:e1962. https://doi.org/10.7717/peerj.1962

González L (2013) Entre la predación y la docilidad. Padecimiento shawi en la alta Amazonía. Tesis doctoral, Universidad Complutense, Madrid

Gracey M, King M (2009) Indigenous health part 1: determinants and disease patterns. The Lancet 374(9683):65-75

Guardiola J, González-Gómez F, Grajales ÁL (2010) Is access to water as good as the data claim? Case study of Yucatan International Journal of Water Resources Development 26(2):219-233. https://doi.org/10.1080/07900621003655692

Harper SL, Edge VL, Willox AC (2012) 'Changing climate, changing health, changing stories' profile: using an EcoHealth approach to explore impacts of climate change on Inuit health. EcoHealth 9(1):89-101
Hofmeijer I, Ford JD, Berrang-Ford L, Zavaleta C, Carcamo C, Llanos E, Carhuaz C, Edge V, Lwasa S, Namanya D (2013) Community vulnerability to the health effects of climate change among indigenous populations in the Peruvian Amazon: a case study from Panaillo and Nuevo Progreso. Mitigation and Adaptation Strategies for Global Change 18(7):957-978. https:// doi.org/10.1007/s11027-012-9402-6

INEI (2008) Censo Nacional 2007 (XI de Población y VI de Vivienda). II Censo de Comunidades Indígenas de la Amazonía Peruana 2007. Lima, Perú.

INEI (2009) Perú Encuesta Demográfica y de Salud Familiar 2007-2008. Retrieved from https://dhsprogram.com/pubs/pdf/ FR234/FR234.pdf

Jaravani FG, Massey PD, Judd J, Allan J, Allan N (2016) Closing the Gap: the need to consider perceptions about drinking water in rural Aboriginal communities in NSW, Australia. Public Health Research Practice 26(2):e2621616

Lardeau M, Healey G, Ford JJR (2011) The use of Photovoice to document and characterize the food security of users of community food programs in Iqaluit, Nunavut. Rural Remote Health 11(2):1680

Leite MS, Cardoso AM, Coimbra CEA, Welch JR, Gugelmin SA, Lira PCI, Horta BL, Santos RV, Escobar AL (2013) Prevalence of anemia and associated factors among indigenous children in Brazil: results from the First National Survey of Indigenous People's Health and Nutrition. Nutrition Journal 12(1):69. https://doi.org/10.1186/1475-2891-12-69

Marco ML, Heeney D, Binda S, Cifelli CJ, Cotter PD, Foligné B, Gänzle M, Kort R, Pasin G, Pihlanto A, Smid EJ, Hutkins R (2017) Health benefits of fermented foods: microbiota and beyond. Current Opinion in Biotechnology 44:94-102. https:// doi.org/10.1016/j.copbio.2016.11.010

Marsh AJ, Hill C, Ross RP, Cotter PD (2014) Fermented beverages with health-promoting potential: past and future perspectives. Trends in Food Science Technology 38(2):113-124

Marshall E, Mejia D (2011) Traditional fermented food and beverages for improved livelihoods. Diversification booklet number 21. FAO. Retrieved from https://www.fao.org/3/a-i247 7e.pdf

McClain ME, Aparicio LM, Llerena CA (2001) Water use and protection in rural communities of the Peruvian Amazon Basin. Water International 26(3):400-410. https://doi.org/10.1080/ 02508060108686932

Miranda M, Aramburu A, Junco J, Campos M (2010) State of the quality of drinking water in households in children under five years in Peru, 2007-2010. Revista peruana de medicina experimental y salud publica 27(4):506-511

Motarjemi Y (2002) Impact of small scale fermentation technology on food safety in developing countries. International Journal of Food Microbiology 75(3):213-229. https://doi.org/10.1016/ S0168-1605(01)00709-7

Nawaz H, Rahman MA, Graham D, Katz DL, Jekel JF (2001) Health risk behaviors and health perceptions in the Peruvian Amazon. Am J Trop Med Hyg 65(3):252-256

O'Sullivan L, Ross RP, Hill C (2002) Potential of bacteriocinproducing lactic acid bacteria for improvements in food safety and quality. Biochimie 84(5):593-604. https://doi.org/10.1016/ S0300-9084(02)01457-8

Ormaeche M, Valdez W (2003) Analisis de la Situacion de Salud de los Pueblos Indigenas. Retrieved from Jesus María 
Ormaeche Macassi M (2008) ASIS del pueblo Shawi 2008-Región Loreto. Retrieved from https://www.dge.gob.pe/portal/docs/in tsan/asis_shawi15.pdf

Peña-Venegas C, Stomph T, Verschoor G, Lopez-Lavalle L, Struik $P$ (2014) Differences in manioc diversity among five ethnic groups of the Colombian Amazon. Diversity 6(4):792-826

Perú (2018) Encuesta demográfica y de salud familiar-ENDES. Retrieved from https://www.inei.gob.pe/media/MenuRecursivo/ publicaciones_digitales/Est/Lib1656/index1.html

Rosinger A, Tanner S (2015) Water from fruit or the river? Examining hydration strategies and gastrointestinal illness among Tsimane'adults in the Bolivian Amazon Public Health Nutrition 18(6):1098-1108

Şanlier N, Gökcen BB, Sezgin AC (2017) Health benefits of fermented foods. Critical Reviews in Food Science and Nutrition . https://doi.org/10.1080/10408398.2017.1383355

Sanlier N, Gökcen BB, Sezgin AC (2019) Health benefits of fermented foods. Critical Reviews in Food Science and Nutrition 59(3):506-527. https://doi.org/10.1080/10408398.2017.1383355

Sedano, J. L. (2006). Selección de cepas nativas de lactobacillus con actividad inhibitoria y tolerantes al etanol aisladas de "masato". (Undergrad), Universidad Nacional Mayor de San Marcos, Lima.

Spence N, Walters D (2012) "Is it safe?" Risk perception and drinking water in a vulnerable population The International Indigenous Policy Journal 3(3):9

Stephens C, Porter J, Nettleton C, Willis R (2006) Disappearing, displaced, and undervalued: a call to action for Indigenous health worldwide. The Lancet 367(9527):2019-2028
Torres-Slimming PA, Wright C, Carcamo CP, Garcia PJ, Harper SL (2019) Achieving the sustainable development goals: A mixed methods study of health-related water, sanitation, and hygiene (WASH) for Indigenous Shawi in the Peruvian Amazon. International Journal of Environmental Research and Public Health 16(13):2429

Watson F, Ngesa A, Onyang'o J, Alnwick D, Tomkins A (1996) Fermentation-a traditional anti-diarrhoeal practice lost? The use of fermented foods in urban and rural Kenya International Journal of Food Sciences and Nutrition 47(2):171-179

Wright CJ, Sargeant JM, Edge VL, Ford JD, Farahbakhsh K, Shiwak I, Flowers C, Gordon AC, Harper SL (2018) How are perceptions associated with water consumption in Canadian Inuit? A cross-sectional survey in Rigolet, Labrador Science of The Total Environment 618:369-378. https://doi.org/10.1016/ j.scitotenv.2017.10.255

Zavaleta C, Berrang-Ford L, Ford J, Llanos-Cuentas A, Cárcamo C, Ross NA, Lancha G, Sherman M, Harper SLAdaption to Climate Change Research, G (2018) Multiple non-climatic drivers of food insecurity reinforce climate change maladaptation trajectories among Peruvian Indigenous Shawi in the Amazon. PLOS ONE 13(10):e0205714. https://doi.org/10.1371/ journal.pone.020571410.1371/journal.pone.0205714

Zavaleta C, Berrang-Ford L, Llanos-Cuentas A, Cárcamo C, Ford J, Silvera R, Patterson K, Marquis GS, Harper S (2017) Indigenous Shawi communities and national food security support: Right direction, but not enough. Food Policy 73:75-87. https://doi.org/10.1016/j.foodpol.2017.10.001 